\title{
Recurrent Small Lymphocytic Lymphoma
}

National Cancer Institute

\section{Source}

National Cancer Institute. Recurrent Small Lymphocytic Lymphoma. NCI Thesaurus.

Code C8154.

The reemergence of small lymphocytic lymphoma after a period of remission. 